\title{
Ross Watkins
}

\section{Remarkable analogue constructions of the author/illustrator: Re-imagining textual spaces of the book as object}

\begin{abstract}
Mark Z Danielewski states: 'Ruler-wielding didacts have instilled in [readers] the notion that a book must start here, move along like this, and finish over there. But books don't have to be so limited. They can intensify informational content and experience. Multiple stories can lie side by side on the page ... pages can be tilted, turned upside down, even read backwards... But here's the joke. Books have had this capacity all along... Books are remarkable constructions with enormous possibilities... But somehow the analogue powers of these wonderful bundles of paper have been forgotten' (Danielewski 2002). Adopting Danielewski's position, this paper is a fictocritical exploration of the practices involved in authoring/illustrating 'Truth Is', a composite illustrated novel about the multiple narratives/truths splintering from one act of heinous violence. Part murder-mystery, part pseudo-documentary, part graphic novel, 'Truth Is' seeks to re-imagine the textual spaces of the 'book as object' as a method of enriching the narrative's thematic explorations. This paper explores the illustrated novels of Jonathan Safran Foer and others researched while creating the novel, and enmeshes this with an exploration of the author/illustrator's intentions and trepidations in encountering the potential of the book as object.

Keywords: author/illustrator, technique, book as object, fictocriticism
\end{abstract}

\section{A note on the fictocritical nature of this paper}

Anna Gibbs establishes fictocriticism as 'a way of writing for which there is no blueprint and which must be constantly invented anew in the face of the singular problems that arise in the course of engagement with what is researched' (Gibbs 2005). Gibbs furthers her point on the necessary reflexivity of fictocriticism, referring to it as 'writing as research, stubbornly insisting on the necessity of a certain process in these days when writing is treated by those who determine what counts as research to be a transparent medium, always somehow after the event' (2005; original emphasis). Fictocriticism is thereby responsive and an embodiment of the research process involved in creative practice amidst the event; the result being experimental and idiosyncratic. Raine explains: 'this form of essay writing is akin to opening up a space in which one's full knowledge has freedom to play and explore', and as such the 'experience should be full of dead ends and wonderings about how things 
work' (Raine 2009). With these values held at the forefront, this paper plaits fictional and critical modes with a second person auto/biographical discourse as a fictocritical exploration of the process involved in writing and illustrating a work of narrative fiction. By using second person narration as a strategy to gain critical distance, the essay itself enacts an 'encounter between the writer's emergent, embodied subjectivity and what is written about' (Gibbs 2005). The use of the ambiguous signifier 'you' also attempts to compel the reader to become complicit in the meaning-making process.

\section{It starts with...}

You are a writer and an illustrator and respectively modest and humble but you have a desire to create a book which makes an impact. Somehow. You don't want to write just another prose novel - you want it to be a remarkable 'thing'. You might be considered a dying breed but you still favour physical books and believe that while the tide flows towards the electronic book the physical book is the format which will allow this desire to materialise.

It starts with a thumb and a road and Bruce Springsteen's 'I'm on Fire'. You hear the song and the story almost starts writing itself to the beat. You write:

Truth is I was on the highway when this diamond come sparkin on my windshield and then it done grew into a girl bout seventeen or so with a pack on her back and a thumb stuck out pointin down the white line. So I pulls up and she leans in and I says where you headin and she says forward ways and I says well thas where I be headin too cause there ain't no nothin behind.

You like the voice and the imagery so you write more and more and the plot and characters take shape - a man tells how he picked up a girl hitchhiking along a highway and as they drive and talk they reconsider what they are attempting to leave behind, eventually parting ways at a roadhouse. The story is told by the driver to an implied officer investigating the implied death of the young woman after the two characters parted ways.

It begins as a short story and soon gets published [1] and there's something about the narrator which has you hooked. You want to write more about him and more about the girl but life moves forward and the dust settles and that's how you let it go.

For now.

A year later you have some time to dream. You dream about the man and the girl and you wonder about what led her to be in that car with him and who did her wrong. So you write a short story which follows on from the previous. Then another. By this time the magnitude of the story could take on novel proportions - the plot has sufficient convolutions and involves multiple characters, and a thematic concern about the reliability and complexity of multiple 'truths' is evolving. You can see this as part murder-mystery, part pseudo-documentary in structure - different people telling their stories about what they saw and what they know and what it all means and the reader plays detective and works out one truth from the next and last.

So the decision to write 'Truth Is' the novel is made. You then look to the next step and set to dreaming all over again and that's when you pick up Foer. 


\section{It starts when...}

It starts when you pick up Jonathan Safran Foer's Tree of Codes (2010) and the book feels vacant in your hands, like it's been gutted or somehow hollowed out. You visualise movies where a prisoner has carved the shape of a weapon into the pages of a book so that the guards won't find the weapon in a shake-down. You like this analogy; it rings true with your impression of what Foer is achieving with his book and something close to what you want for your own the gaps can signify just as effectively or perhaps even more so than the words that are left to be read. These silences are a weapon. Or, these silences can accommodate the weapon of the reader's own devise.

Stefans rightly points out that Tree of Codes is 'a text entirely drawn from the text of Bruno Schulz's 1934 short story collection Street of Crocodiles. Tree of Codes makes a new fiction (complete sentences, characters, narrative arcs, etc.) out of the original text by physically subtracting, as with a razor, those parts of Schulz's pages Foer chose not to utilize in his new text' (Stefans 2014: 163164). Stefans goes on to quote the publisher's description of the book as a 'sculptural object' (2014: 164) and says that 'what this dramatizes, in ways normal books do not, is the inaccessibility of the past by the present. Once you turn a page, you are left with a blank reverse-silhouette of the page you have just read, the form of the reading without the letters' (2014: 179). This analysis is consistent with Foer's description of what he made: 'At times I felt that I was making a gravestone rubbing of The Street of Crocodiles, and at times that I was transcribing a dream that The Street of Crocodiles might have had' (Foer 2011: 139).

Foer's book reminds you of the challenge Mark Z Danielewski put out there when he said:

Ruler-wielding didacts have instilled in [readers] the notion that a book must start here, move along like this, and finish over there. But books don't have to be so limited. They can intensify informational content and experience. Multiple stories can lie side by side on the page ... pages can be tilted, turned upside down, even read backwards... But here's the joke. Books have had this capacity all along... Books are remarkable constructions with enormous possibilities... But somehow the analogue powers of these wonderful bundles of paper have been forgotten. (Danielewski 2002)

With two young children about the house you're regularly reminded of books as analogue objects. The boys like playing on your tablet device but to them a 'book' is still the book you grew up knowing. Books spill from bookshelves in their bedroom and they litter the coffee table and most times the floor. The boys meander through their pages, occasionally throw them, and your eldest likes to smell them. Sure, he reads books too but often you walk into the lounge room and find him sitting up on the couch with his nose buried deep in the fold of a book, inhaling. When you see this you wonder about children's wonder at the book as an analogue construction and you start asking questions.

Children's publishing embraces the tactile qualities of the book - books pop-up and unfold, they have sliding panels and corrugations and cut-outs and fur, and sometimes they even force the reader to turn the book on its side in order to be read. All this draws attention to the spatiality of the book, and books for children regularly use typography as an essential component of their design in 
communicating thematic and dramatic intent. Like Foer's intentions, the design of children's literature is far from frivolous: as Brown says in discussing eighteenth century children's literature, the 'tactile contribution to the experience of the book foregrounds the reader's part in the making of the meaning of the book' (Brown 2006: 358).

So you ask: when do these spatial shenanigans become inappropriate or immature for the adult market? Or, perhaps more accurately: when do these spatial strategies become literary eccentricities in the face of convention literary oddities experimented with by creators such as Foer and Danielewski in more recent times? Part of you also asks: why should kids have all the fun?

\section{It actually starts with...}

It actually starts with a different book altogether.

As well as a writer and an illustrator you are an academic and all this questioning brings to mind Brian McHale's Postmodernist Fiction (1987) in which he says:

The invention of printing embedded the word in space... While a manuscript could still be regarded as the record of an oral performance, a book was a thing, and its material qualities and physical dimensions inevitably interacted with the word. Far from exploiting this interaction, however, fiction in the realist tradition has sought to suppress or neutralize it; realist fiction, says Sukenick, "tends to deny its technological reality." It does so by conventionalizing space right out of existence. Nothing must interfere with fiction's representation of reality, so the physical dimensions of the book must be rendered functionally invisible... Indeed, the functional invisibility of space in prose fiction is what distinguishes prose from verse, with its conventions of the unjustified right margin and stanza breaks. Spacing is the sign of verse; prose, the unmarked member of the pair, is identified by its spacelessness. (McHale 1987: 181; original emphasis)

You pull a book of poetry from the shelf - any one - and it's Lawrence Ferlinghetti's A Coney Island of the Mind (1958). You flick through and read 'Dog' and you realise how in this poem spatiality impacts on tone and this tone comes to impact upon the impression of the poem's thematic intent. Specifically, the placement of the verbal text starts out as conventional left alignment without indentation; yet at the point where the dog realises his potential as 'a real live barking democratic dog' the dog's tail swings and the words take on a new form, a new fluidity as they sprawl across and down the page, pausing for breath only when the words either come back to fully left alignment or just further left before the cadence finds its ebb and flow, contributed to by Ferlinghetti's use of enjambment. There is no doubt that Ferlinghetti had an intention and one probably far more complex than such a brief appraisal as this, but still 'Dog' shows you McHale's statement in application - typographical design can create meaningful effects on a reader's interaction with the text on multiple levels.

Your attention turns to fiction because many fiction authors have of course adopted these semantic strategies in prose (and not all of them necessarily for postmodern or post-structural objectives). Lawrence Sterne's seminal abstract illustrated prose novel The Life and Opinions of Tristram Shandy (1759-67) is 
an historic case in point, in which he utilised the abstract potential of punctuation (symbolic graphemes) and sous rature (strikethrough) and pictograms as devices for controlling pace and portraying breathing and hesitation and as self-referential parody. Amongst other things. William $\mathrm{H}$ Gass' Willie Masters' Lonesome Wife (1968) combines photographic images with typographical disparity, including the use of font to amplify the aesthetics of language, and experimental 'concrete' prose layout resembling the Guillaume Apollinaire's Calligrammes (1918). These strategies bear direct relevance to the prose, most often in metafictional ways; for instance, a double page spread (Gass 1971: 8-9) where page right is literally mirrored (reversed) on page left may be interpreted as the physical manifestation of the sentence:

Then I am as it is, reflecting on my own revolving, as though a record might take down its turning and in that self-responsive way comprise a song which sings its singing back upon its notes as purely as a mirror, and like a mirror endlessly unimages itself, yet is none the less an image... (9)

Raymond Federman's Double or Nothing (1992) features extreme radicalisation of the page's conventionality through typography and vectorbased graphics - which Oppermann and Oppermann call the 'typographical pulverisation of language' (1997: 47). In Double or Nothing, a concrete novel, no two pages are composed alike as its narrative winds and leaps through disjuncture after disjuncture of a narrator/writer or 'noodler' (Federman 1998: 0000) telling of his artistic struggles on the page; 'Instead of telling a story, the novel turns into a kind of dialogue between the writer and his text ... and discusses the story's aesthetic mode of representation' (Oppermann \& Oppermann 1997: 46). While you're impressed with this destabilisation and distortion of reading conventions, conceiving the process of putting such a work together overwhelms and anyway you're aiming for something far less alienating.

Adam Thirlwell's Kapow! (2012) is closer to home. Kapow! enacts similar typographical strategies to Danielewski's House of Leaves, a far less radical experiment but an experiment nonetheless in the use of digressive narrative threads which intersect the conventional typography and its linear reading experience. Irregular blocks of text cut into and manipulate the McHale's 'realist' composition of type, these blocks operating as footnotes meant to be accessed at points designated with the use of an abstract symbol.

In Extremely Loud \& Incredibly Close (2005) Foer explores an array of typographical devices, of which space is the prime signifier. His uses are as simple as the presentation of the French conjugations of nine-year-old narrator Oskar as he tries to lull himself to sleep - the conjugations uttered are italicised and 'stepped' down and across the page (similar to Ferlinghetti's dog), as if to replicate Oskar's descent into sleep until the final 'Nous' (Foer 2005: 74). Other examples are more complex: the chapter entitled 'GOOGOLPLEX' has a three-quarter page block of justified text which serves to further compound the underplayed emotional intensity of the lone word 'Help' on the previous page, centred and in utter isolation (2005: 34-35); the use of protracted spaces between sentences signifies chapters 'written' to Oskar from his grandmother and seem to capture something of the careful articulation (pace and hence tone) of her iterations; a literally blank page portrays the stack of literally blank pages of her life story typed out on a typewriter without a ribbon (2005: 120121); fragments of somewhat incoherent italicised text, sporadically pieced-out across several pages, capture snatches of overheard conversation (2005: 205207). There are further examples, the most dramatic being where Oskar's grandfather is writing in his journal to his son who died in the September 11 
World Trade Centre attacks and the typography's leading and kerning become progressively tighter and tighter until the words crunch into each other - as though each line has been written over the top of another - and eventually solidify into a block of black, a representation of the trauma experienced in the aftermath of the event and echoing the narrator's childhood experiences of the bombing of Dresden (2005: 281-284).

$\mathrm{Hm}$.

These are some of your creative influences and some of your ideas and some of your intentions. You are spurred on. And the illustrator in you is reaching out the illustrator wants to fill some of those silences with images or help create further silences and push into the spaces of the book to carve out some new relevance and meaning. You begin to visualise the book not as a manuscript but as a 'thing'. You have some words down and this is essential because the words almost always come first so that the illustrations have an anchor point or a point of reference to create a point of difference - that is, you don't want the illustrations to simply mirror the prose: they must add new or alternate or conflicting information for the reader to interpret so that the reader can explore the novel's content in an enriched and enriching way (everything from its setting and tone to its characters and events and what this all might mean - it's a meaning-making process).

You turn to Johanna Drucker who is useful here in pointing out that the graphic elements of a text are not only navigational devices, their placement and content manoeuvre the reader's construction of meaning: 'Graphic devices don't just "serve up" such narratives in some decorous manner. They are frequently integral and substantive aspects of meaning' (Drucker 2008: 125). You and Drucker hold similar aims. She says,

I want to demonstrate that graphic devices contribute to story, that they are part of that chronological sequence of events and introduce links of causality... I want to demonstrate that graphic devices model the discourse field in ways that constraint [sic] or engineer the narrative possibilities for a reader. (Drucker 2008: 124)

In your novel you want the reader to interact with the story in such a way that they are manipulated by each character/narrator's portrayal of their 'truth'. You want them to question what they are being told by each character/narrator so you begin to map how this could be achieved. You imagine a black line, like ink running down the page, which guides the reader's navigation and overtly signifies shifts in direction. Danielewski used straight horizontal and vertical lines and boxes in House of Leaves (Danielewski 2000) to partition information, and you visualise something similar. The line/s will be a metaphoric road for not only the characters but also the reader. The road is the returning point - no matter where the plot takes them they always end up back on the road. And the road can turn. You visualise the prose starting out conventionally formatted but then the next chapter forces the reader to turn the book on its side and the road tells them it's okay, follow me. The next chapter does the same so that the reader is now reading the book in a reverse direction to move forward to the next page. And then the next chapter turns again and the next one turns again so that the reader is back in conventional territory, having travelled full circle. Truth travels a full circle, which brings about the novel's resolution. (See Figures 1-4.) 


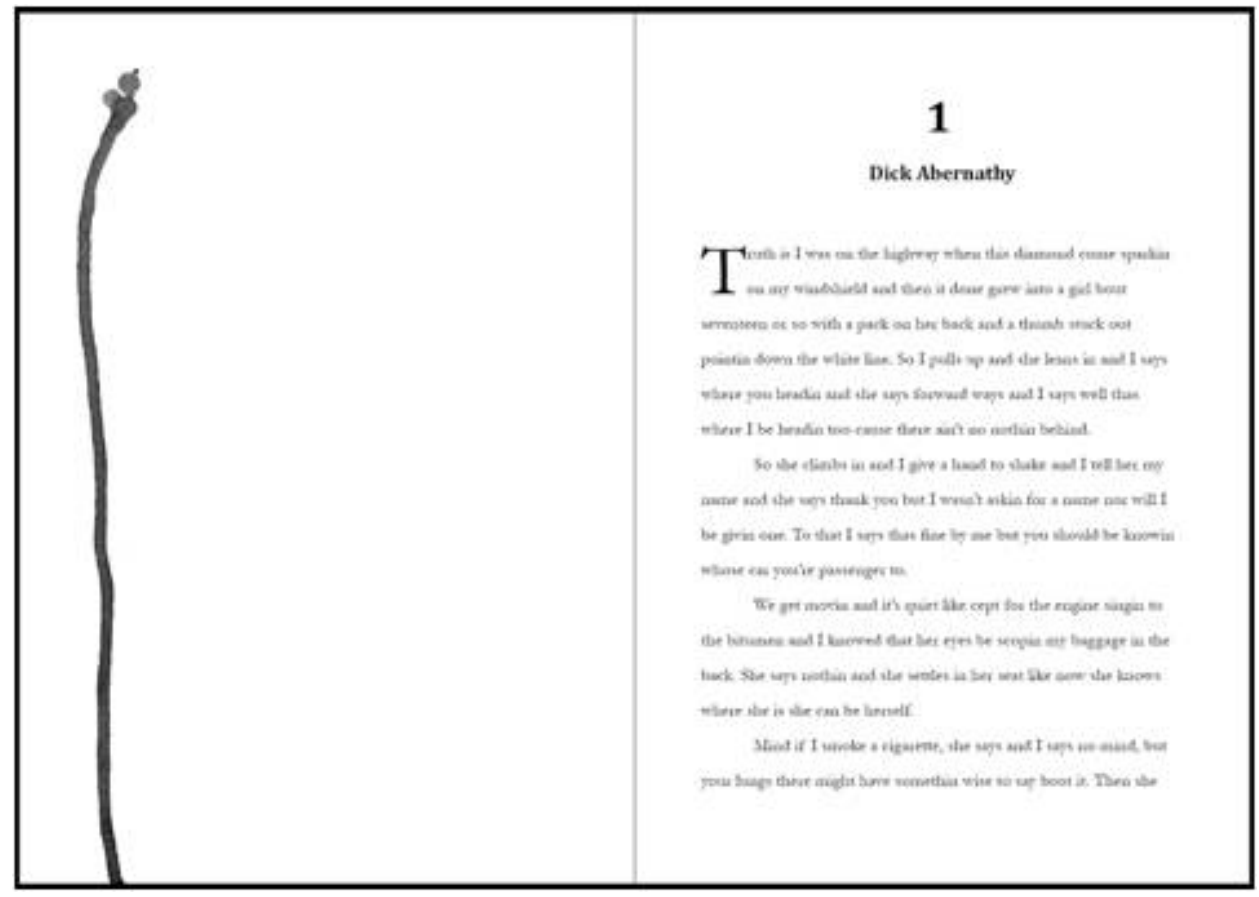

Figure 1. 'Truth Is' mock-up. Rotation concept. September 2014.

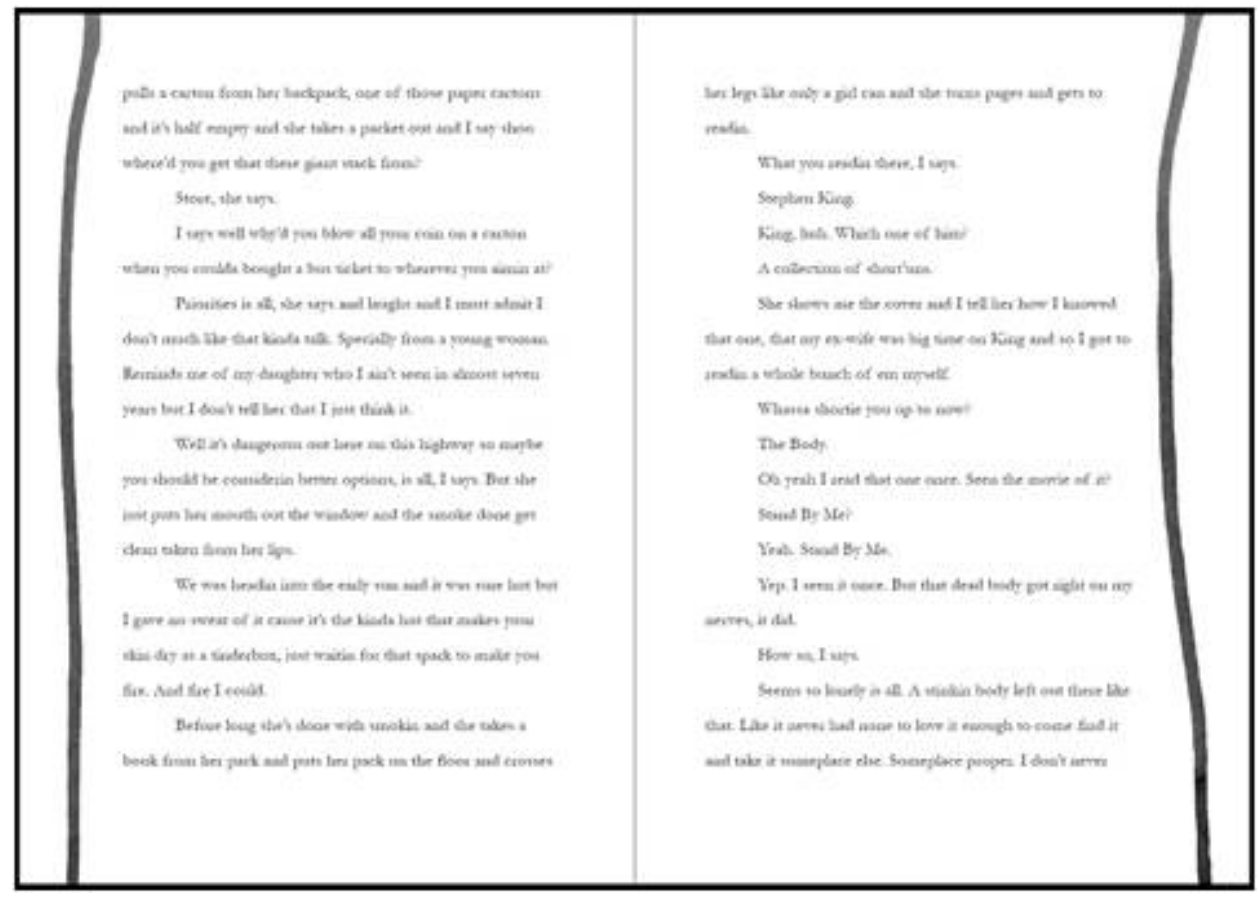

Figure 2. 'Truth Is' mock-up. Rotation concept. September 2014. 


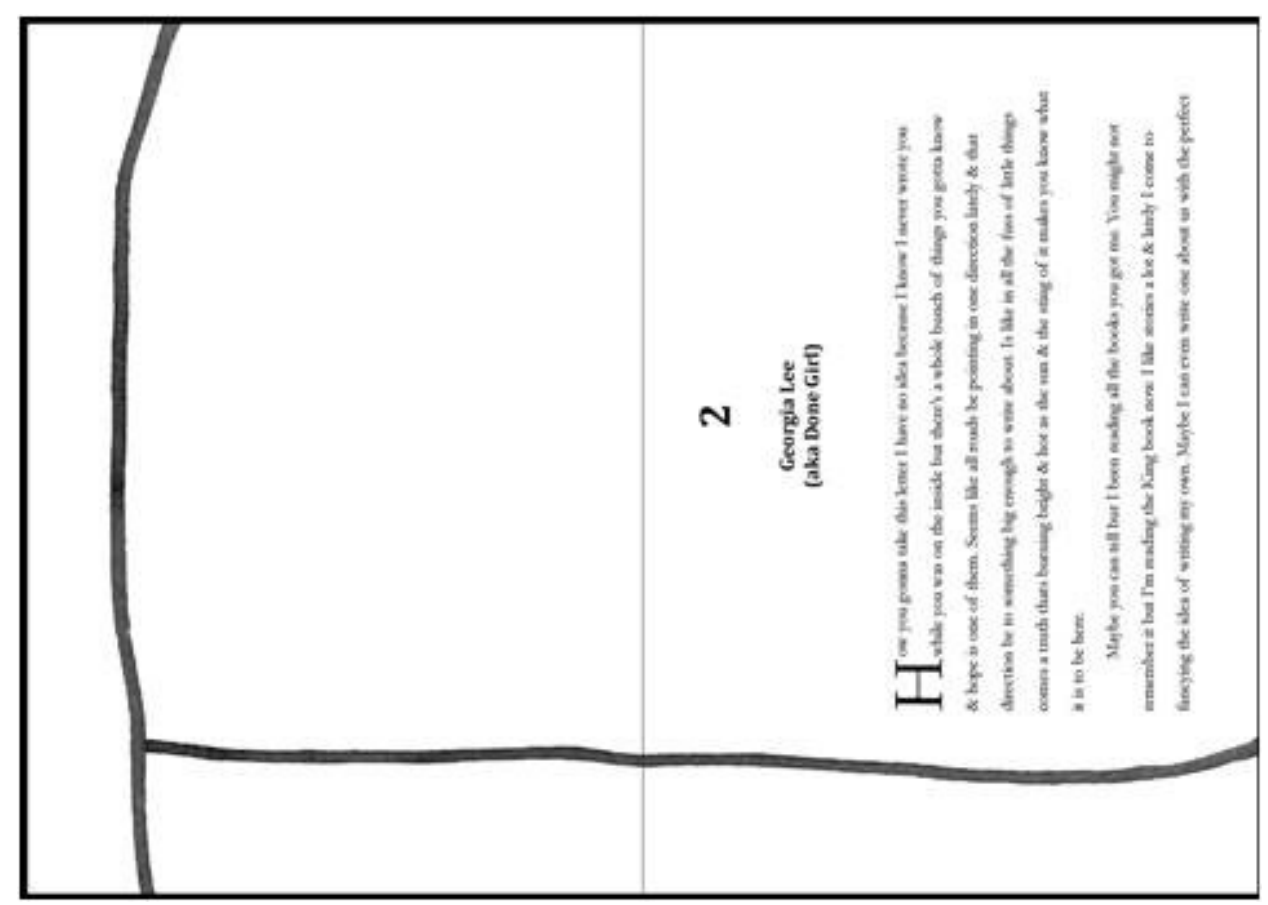

Figure 3. 'Truth Is' mock-up. Rotation concept. September 2014.

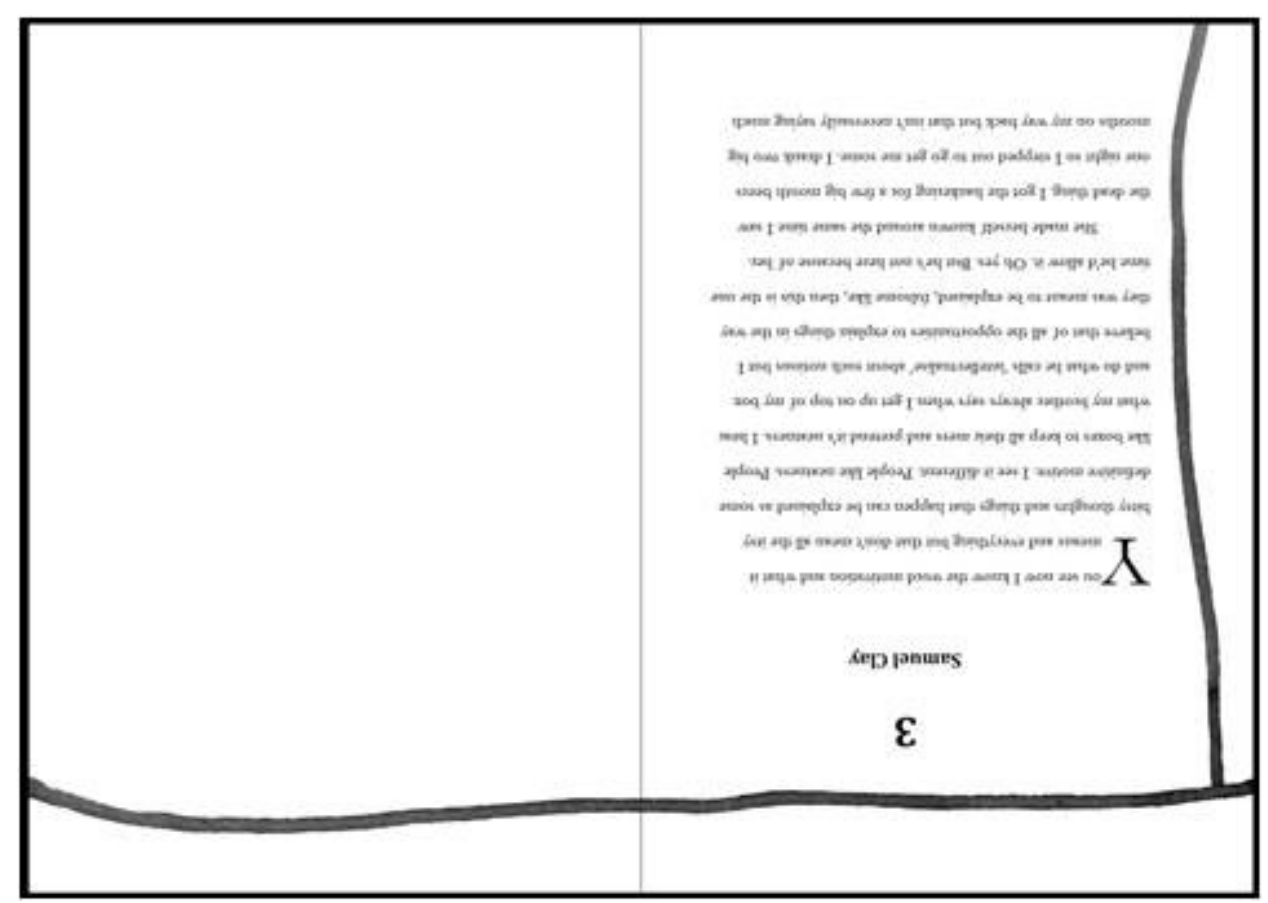

Figure 4. 'Truth Is' mock-up. Rotation concept. September 2014.

Another typographical/spatial idea arises: some characters' stories could be presented side-by-side so that the conflict of those stories or the narratorial deviations are made apparent and a new story can emerge from the juxtaposition. Because you're an academic you also visualise writing about this in a scholarly paper as a fictocritical exploration of the processes and practices involved in creating such a 'thing'. You even see the line performing a similar function in the paper, but this venture will prove too ambitious for the format so the idea has to be abandoned.

You take the notebook given to you when you completed your doctorate and you make notes and draw pictures with a lovely black felt-tip pen. You write suggestions to yourself and reminders of what not to forget. You list potential 
illustrations and potential media. You're not a dinosaur and especially not a Luddite - quite the opposite, in fact, as the digital workspace is integral to your creative process. You experiment with linocut block printing and these illustrations are digitised via a scanner and modified and prepared and 'placed' using graphics and publishing software. Hares feature as a motif because the girl in the novel dreams about hares as a portent of her death. You think about how illustrations could open new spaces on the page and you have the idea to use zooming and panning and the book's 'gutter' with illustrations straddling page turns. (See Figures 5-7.)

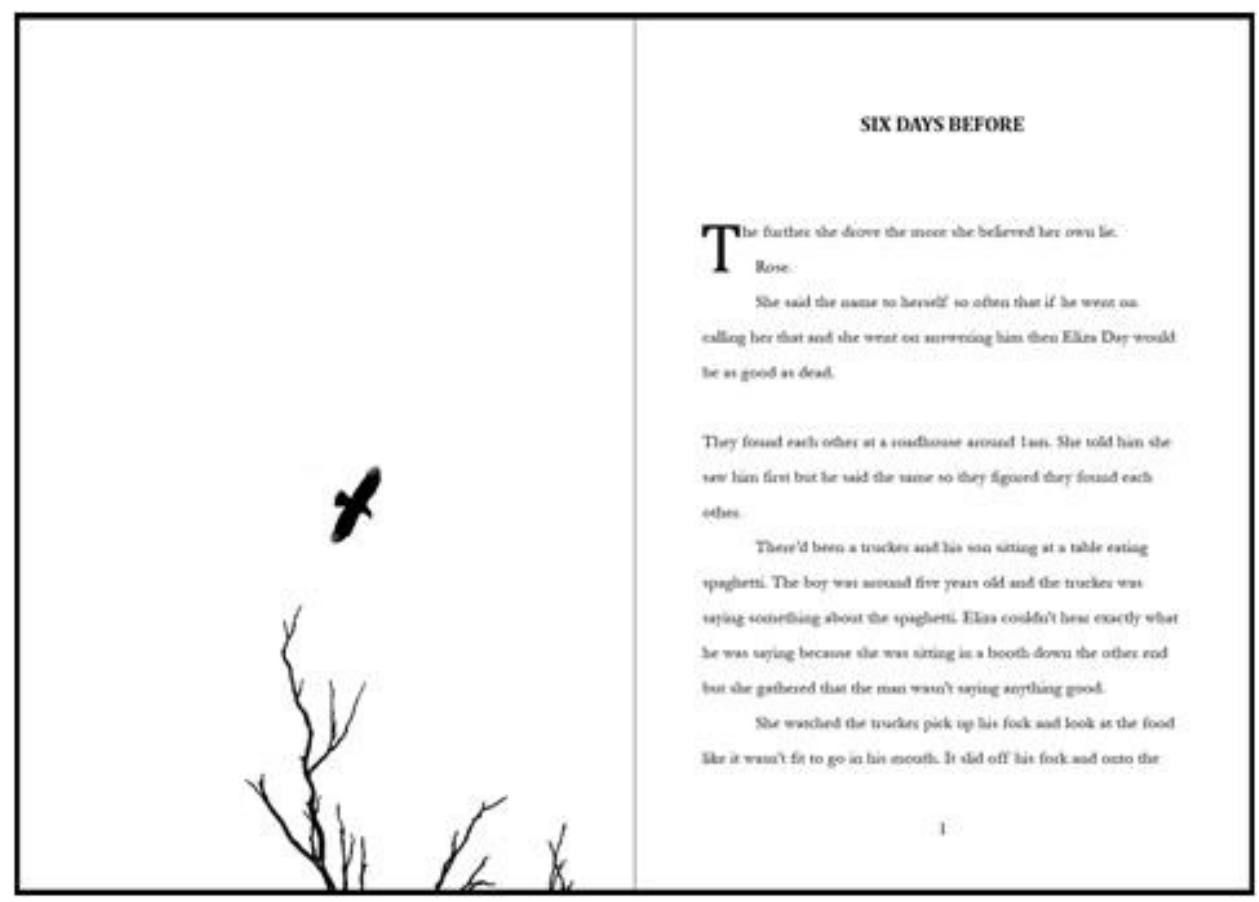

Figure 5. 'Truth Is' mock-up. Panning concept. November 2014.

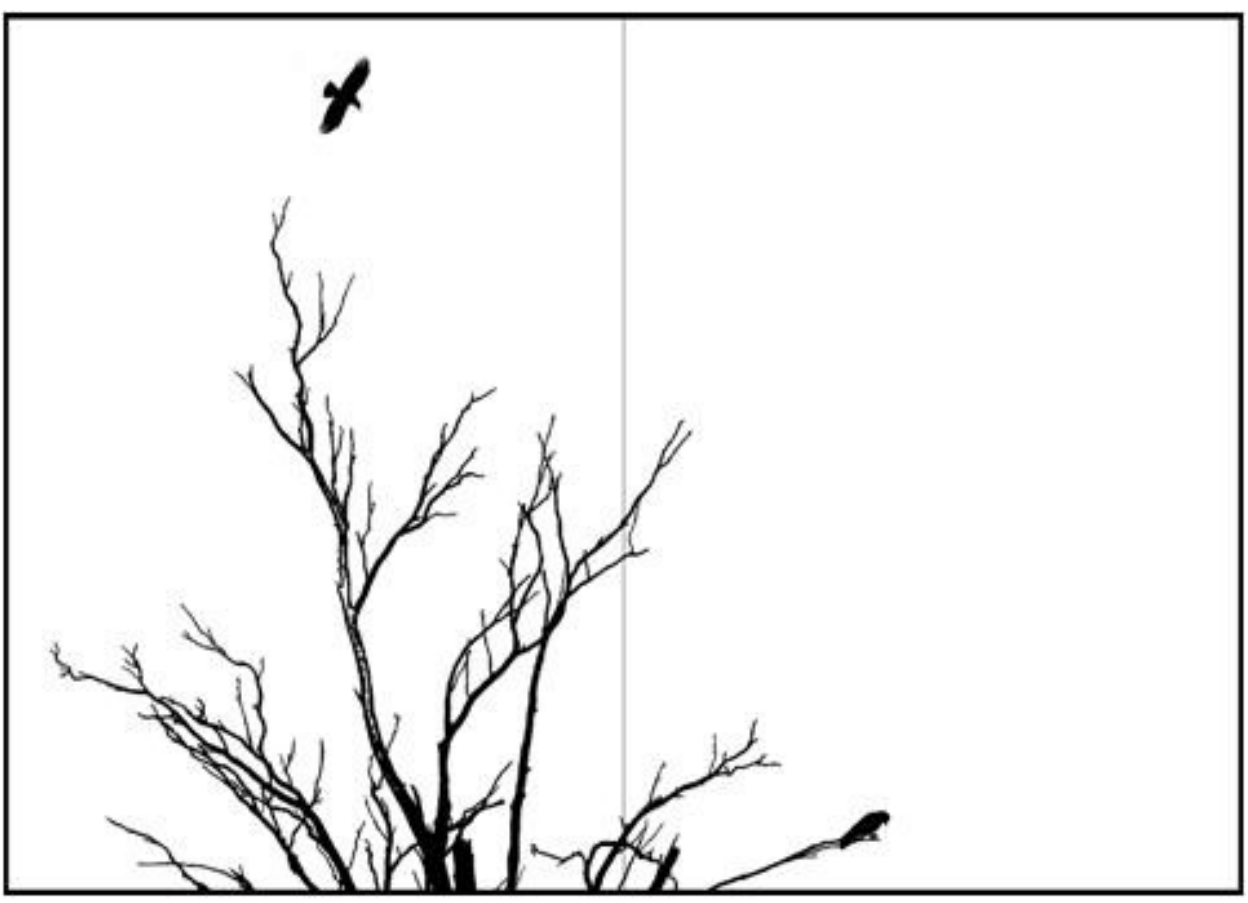

Figure 6. 'Truth Is' mock-up. Panning concept. November 2014. 


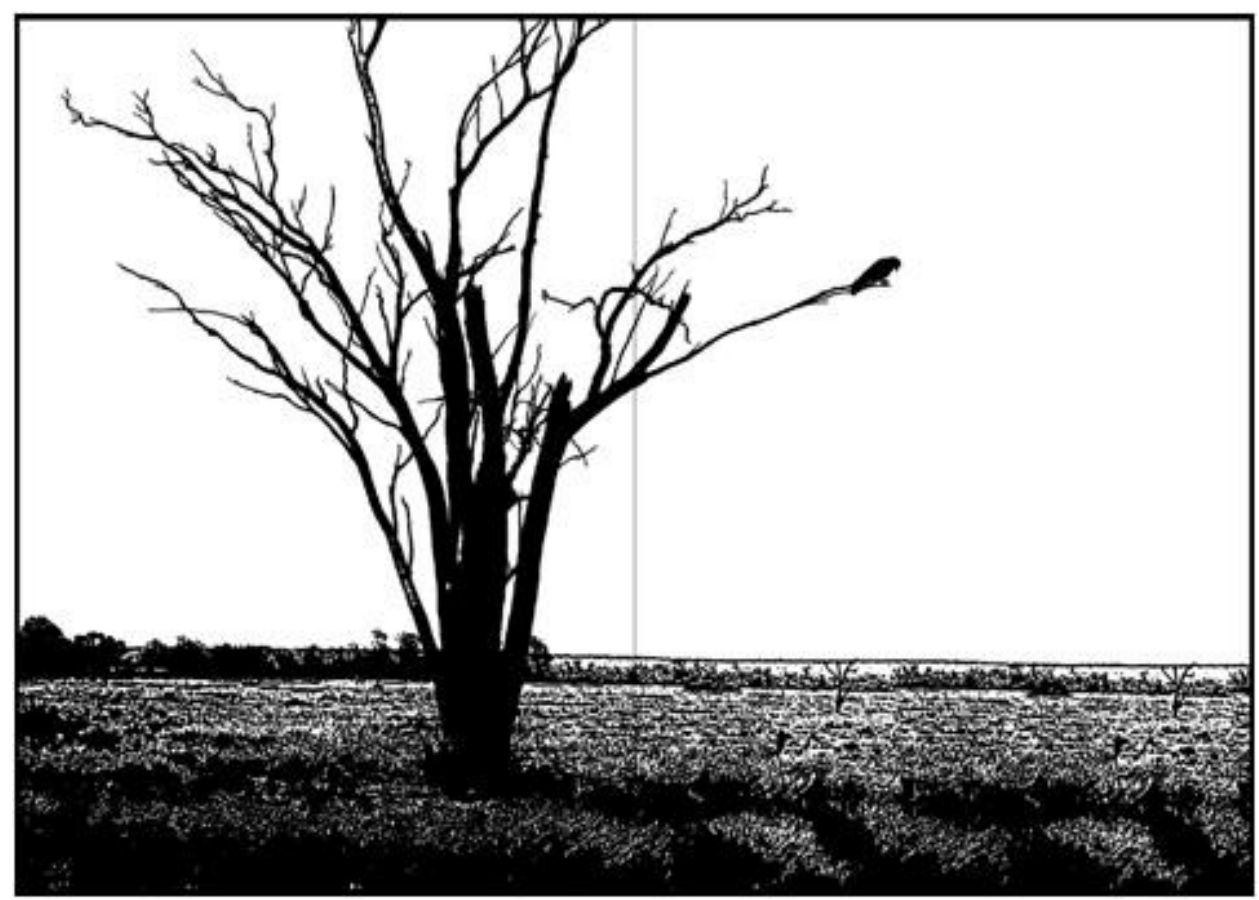

Figure 7. 'Truth Is' mock-up. Panning concept. November 2014.

This is it, you think. The book as object. The novel you wanted to make impact. Somehow.

This is it, you think.

You think...

I'm not there yet...

I'm not there yet, you say. This is a work-in-progress, you say. But it's not going to work. Not anymore. Life moves forward and the dust settles and that's how you let it go.

For now.

A year later you have some time to dream. You dream about the man and the girl and you know that in your mind the book will have to change if it is to be published. The reality of the pressures of the local publishing market get to you and you know the story has to find more appeal for Australian readers and you know that the typographical/spatial strategies are more likely to bamboozle conventional publishers and readers. And you want this book to become a 'thing' - a real thing out there on a shelf. Maybe even your sons' bookshelves one day, when they're older. So you need a new strategy.

You gauge your hesitation at the page and you recognise that it will all work out fine. It's just part of the creative process. It's just part of trying to push the boundaries of literary convention. You just need to keep pushing, is all. Foer did it and Danielewski did it and his words echo in your mind: 'books don't have to be so limited. They can intensify informational content and experience' (Danielewski 2002).

This is it, you think. You have to ensure that someone somewhere someday will not forget the 'analogue powers of these wonderful bundles of paper'

(Danielewski 2002).

You think... 


\section{Notes}

[1] Watkins, R 2011 'Truth Is', The Australian Literature Review: http://auslit.net/2011/11/22/truth-is-by-ross-watkins/ return to text

\section{Works Cited}

Brown, G 2006 'The Metamorphic Book: Children's Print Culture in the Eighteenth Century', Eighteenth-Century Studies 39, 3 (Spring): 351-362 return to text

Danielewski, MZ 2000 House of Leaves, Pantheon Books, New York return to text

Danielewski, MZ 2002 ‘A Conversation with Mark Danielewski’, Interview by Sophie Cottrell (last modified April 28):

http://www.randomhouse.com/boldtype/0400/danielewski/interview.html (accessed 15 July 2014) return to text

Drucker, J 2008 'Graphic Devices: Narration and Navigation', NARRATIVE 16, 2 (May): 121139 return to text

Federman, R 1998 [1992] Double or Nothing: a real fictitious discourse, 3rd edition, Fiction Collection Two, Normal IL return to text

Ferlinghetti, L 1958 A Coney Island of the Mind, New Directions, New York return to text

Foer, JS 2005 Extremely Loud \& Incredibly Close, Penguin, London return to text

Foer, JS 2011 [2010] Tree of Codes, Visual Editions, London return to text

Gass, WH 1971 [1968] Willie Masters' Lonesome Wife, Knopf, New York return to text

Gibbs, A 2005 'Fictocriticism, Affect, Mimesis: Engendering Differences', TEXT 9, 1 (April): http://www.textjournal.com.au/april05/gibbs.htm (accessed 2 August 2014) return to text

McHale, B 1987 Postmodernist Fiction, Routledge, London return to text

Oppermann, S \& M Oppermann 1997 'Raymond Federman's Double or Nothing: A

Prolegomena to a Postmodern Production Aesthetics', American Studies International XXXV, 3 (October): 42-66 return to text

Raine, D 2009 'Essaying the Self: Ethnicity, Identity and the Fictocritical Essay', TEXT Special Issue 5 (April): http://www.textjournal.com.au/speciss/issue5/raine.htm (accessed 2 August 2014) return to text

Stefans, BK 2014 'Terrible Engines: A Speculative Turn in Recent Poetry and Fiction', Comparative Literature Studies 51, 1: 159-183 return to text

Sterne, L 2000 [1759] The Life and Opinions of Tristram Shandy, Oxford University Press, Oxford return to text

Thirlwell, A 2012 Kapow!, Visual Editions, London return to text

Ross Watkins is an author, illustrator and editor. His first major publication is the illustrated book The Boy Who Grew Into a Tree (Penguin Books, 2012), and One Photo (Penguin Books) is due for release early 2016. His work has been shortlisted for various prestigious awards, and his short fiction and nonfiction have been published in Australian and international anthologies. Ross is a Lecturer in Creative Writing at the University of the Sunshine Coast, Queensland. 


\section{TEXT}

Vol 19 No 1 April 2015

http://www.textjournal.com.au

General Editor: Nigel Krauth. Editors: Enza Gandolfo \& Linda Weste text@textjournal.com.au 